\title{
Drivers of Celebrity Endorsement and Its Effect on Consumer's Buying Behavior: A Case Study of FMCGs in Peshawar
}

\author{
SHAHZAD KHAN \\ Assistant Professor, University of Haripur, Haripur \\ PhD-Scholar, International Islamic University, Islamabad \\ shahzadkhan.lecturer@gmail.com \\ SAQIB SHAHZAD \\ Demonstrator, Abdul Wali Kahn University, Mardan \\ PhD-Scholar, Institute of Management Sciences, Peshawar \\ Saqibshahzad26@mail.com \\ NAUMAN HABIB \\ Assistant Professor, City University of Science and I.T, Peshawar \\ PhD-Scholar, Institute of Management Sciences, Peshawar \\ habib_nauman@hotmail.com \\ GHAYYUR QADIR \\ Lecturer, Abdul Wali Khan University, Mardan
}

\begin{abstract}
Because of a business environment of cut-throat competition, companies must find ways to strike for survival and sustain a competitive position in the market. Celebrity endorsement is one of the strategies which companies frequently used to promote the brand thus enhance sales and ultimately increase market share. There are a number of researches which investigated the effects of celerity endorsement on consumers' buying behavior. However, traits such as credibility, expertise attractiveness and compatibility of celebrity endorsers have not been investigated. Therefore, this research is to investigate effects of celebrity endorsement on consumers' buying behavior. In order to obtain a more reliable result, a quantitative research is carried out to investigate the topic. In general it was found that which trait of a celebrity is most significant in influencing consumer buying behavior. For instance the credibility, expertise, attractiveness and compatibility of the endorser were found to be the most important traits of the celebrity that can influence consumer buying behavior. Generally the effect of celebrity endorsement is found to have little direct impact on consumers' purchase decision, yet it is still an effective strategy because it is suggested as a good way to grab consumers' attention. This research also suggests some criteria for selecting the celebrity endorsers with the right attributes for their products. Therefore companies are recommended to conduct sufficient research in order to generate the best effect of a celebrity endorsement.
\end{abstract}

Key words: Celebrity Endorsement, Consumer's Buying Behavior, business environment, brand, market share 


\section{Introduction}

Currently different businesses are thinking of various options and ways in advertisement which they could adopt in order to boost up their sales. One of the strategies adopted by various brands around the globe is Celebrity usage, the reason behind this can be to gain attention of the customers and to create association and also to gain profit. Celebrity endorsement has become a very prominent, profitable and useful mean of advertising and promoting the brand and is been adopted worldwide by different firms producing or offering several brands. According to Silvera and Austad (2004) celebrities are persons who enjoy public appreciation among a huge and vast cluster of people and possess distinctive qualities like attractiveness and trustworthiness. Some examples of celebrities include, actors e.g. Shah Rukh Khan, Ranbeer Kapoor, Ranveer Singh, models Victoria Bekham, sports figures e.g. Christiano Ronaldo, Maria Sherapova.

\subsection{Problem Statement}

The products with high prices have not been studied in the geographical spread of Peshawar. The current study is an attempt to find out the effect of drivers of celebrity endorsement on consumer buying behavior.

\subsection{Research Objectives}

- To examine the consumer's perception towards celebrity endorsements.

- To study the effect of celebrity endorsement on consumer's buying behavior.

- To evaluate the effect of credibility on consumer's buying behavior.

- To identify the effect of expertise on consumer's buying behavior.

- To explore the effect of attractiveness on consumer buying behavior.

- To study the effect of compatibility on consumer buying behavior.

\section{Literature Review}

Boorstin stated, "A sign of a celebrity is that his name is often worth more than his services. Celebrities are people who enjoy public recognition and who often have distinctive attributes such as attractiveness and trustworthiness. (McCracken, 1989a).The more the celebrity is considered trustworthy and credible, the more he/she is able to change the attitude and behavior of the consumer and attract the consumers towards the product he/she is endorsing. According to Tripp, Jensen and Carlson (1994) those celebrities who had endorsed many or several kinds of products would be viewed as less credible as compared to the celebrities who had endorsed only one product. Expertise of a celebrity endorser should relate to the product he/she endorses (Till \& Busler, 1998). Usually, the expertise of a celebrity can be determined from his/her success field. The more success the celebrity gains from his/her career, the more expert he/she is perceived in that field. Attractiveness doesn't only mean physical attractiveness; instead it includes the personality dimensions of the endorser and the lifestyle of the endorser. Research findings show that attractive endorsers are good at influencing the beliefs of customers (Debevec \& Kernan, 1984). An advertisement in which the celebrity and the brand or products are highly compatible yields to be more influential. The companies are trying their best to achieve this congruency in order to successfully attract the consumers or the 
target audience towards their brand. If there is no connection between a celebrity endorser and product; a celebrity and consumer, the only result is audiences remembering the celebrity, but not the product (Evans, 1998). Celebrity endorsements have been accepted to be a ubiquitous feature of modern day marketing\| (McCracken, 1989b). It has also been seen that one quarter of all advertisement use/feature a celebrity to endorse a product or brand. This authorizes the effectiveness of Celebrity endorsements as a means of influential communication. It has the potential to enhance audience attentiveness, make the ad more memorable, credible, and desirable and add fascination to the endorsed product (Spielman, 1981). Perner (2009) defined consumer behavior as "The study of individuals, groups, or organizations and the processes they use to select, secure, use, and dispose of products, services, experiences, or ideas to satisfy needs and the impacts that these processes have on the consumer and society." According to Perner (2009) knowledge of consumer buying behavior helps marketers in developing their marketing tactics by understanding the psychology of the consumers as how

- They feel, think, discriminate, and select between different brands or products.

- The consumer is inclined by his or her environment (e.g., culture, family, and media);

- Consumers behavior while making purchase choices;

- How consumer drive and choice vary among goods that contrast in their degree of significance; and

- How sellers can adjust their marketing promotions and to influence the consumer more commendably.

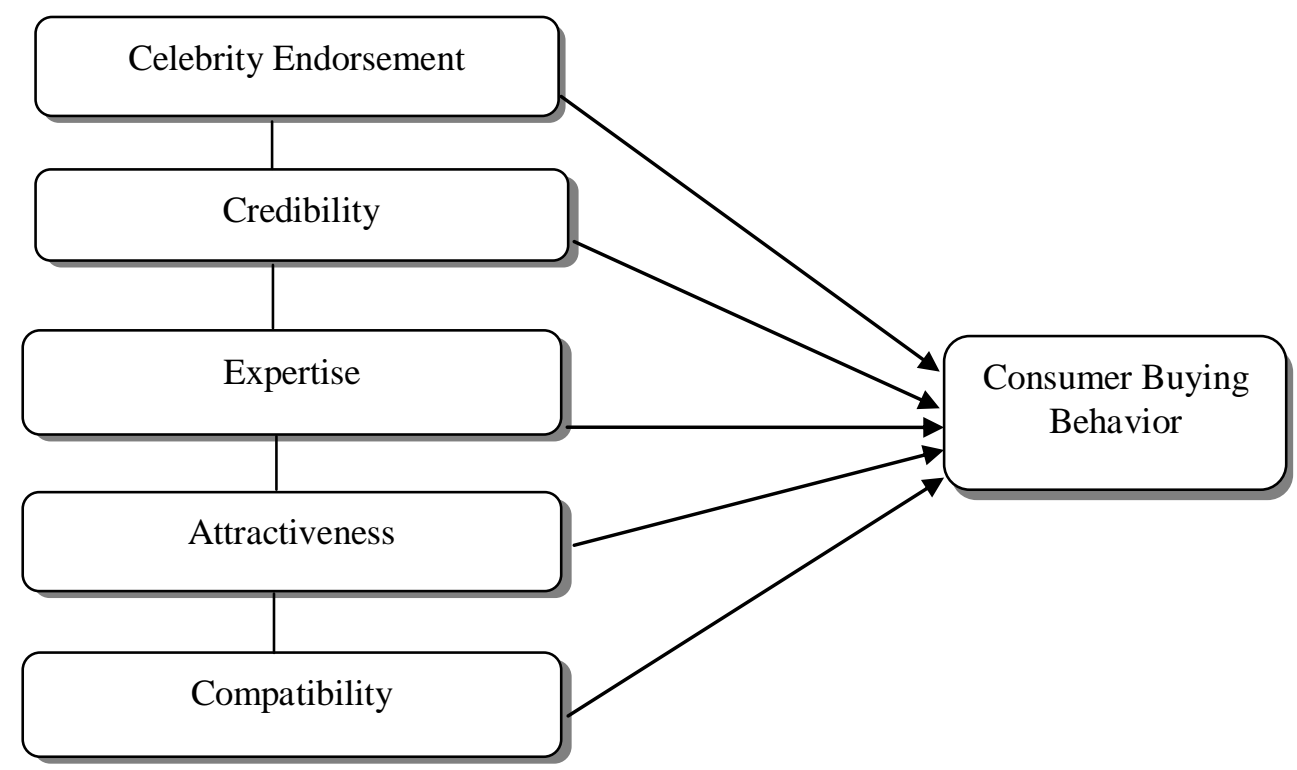

Figure 1: Theoretical Framework 


\subsection{Hypotheses of the Study}

The following hypothesis were tested in the study

$\boldsymbol{H}_{1}$ : Celebrity endorsement has significant effect on consumer buying behavior.

$\boldsymbol{H}_{2}$ : Credibility of celebrity endorsement has significant effect on consumer buying behavior.

$\boldsymbol{H}_{3}$ : Expertise of celebrity endorsement has significant effect on consumer buying behavior.

$\boldsymbol{H}_{4}$ : Attractiveness of celebrity endorsement has significant effect on consumer buying behavior.

$\boldsymbol{H}_{5}$ : Compatibility of celebrity endorsement has significant effect on consumer buying behavior.

\section{Methodology}

This section discusses the methodology adopted in this research study. It highlights the source of data collection and different models used to confirm or reject the hypothesis of the study. Primary data is been collected in order to conduct the research through questionnaire while the secondary data is collected from various journals, articles and websites. The sampling unit consists of the consumers of the FMCG products. The population selected for conducting the research includes consumers of FMCG products such as soap, beauty cream, shampoo etc. and also on specialty goods such as mobile phones, camera, laptops etc. in Peshawar region. The sample size of 100 is proposed to be drawn from the area of interest i.e. Peshawar city which represents the whole population of Peshawar city. The respondents are selected on convenience basis from Peshawar city. The response of the customers is basically measured on the FMCG products. The totals of 98 questioners were returned and the result is based on those 98 responses. This study comprises of the use of quantitative data to test the hypotheses related to celebrity endorsement and its impact on consumer purchase attitude towards products. Survey research method is been used in this research using structured questionnaire as a source of primary information gathering and data collection in Peshawar region. Data is been collected through questionnaire from the respondents on the spot. The questionnaire consists of four parts. The first part consist of the questions related to network quality and coverage factor, the second part consists of the questions related to price factor, the third part consists of the questions related to brand image factor, while the fourth part consists of the questions related to the promotion factor. The data collected from the questionnaires distributed randomly among the respondents of the study was entered in SPSS (statistical package social science). After entering the data in SPSS, the results of descriptive statistics and regression were obtained for the analysis of the study. 


\section{Results and Findings}

Table 4.1: Validity and Reliability Analysis

\begin{tabular}{|c|c|c|c|c|c|c|c|}
\hline S\#. & Questions & \multicolumn{5}{|c|}{ Validity } & \multirow[t]{2}{*}{ Reliability } \\
\hline & & Deter... & KMO & Anti.I & TVE & Comp. & \\
\hline & Credibility & \multirow[t]{5}{*}{0.92} & \multirow[t]{5}{*}{0.000} & \multirow{5}{*}{$\begin{array}{l}.864 \\
.812 \\
.866 \\
.348\end{array}$} & \multirow[t]{5}{*}{76.21} & \multirow{5}{*}{$\begin{array}{l}.855 \\
.892 \\
.851 \\
.894\end{array}$} & \multirow[t]{5}{*}{.875} \\
\hline CRF1 & $\begin{array}{l}\text { I trust on my favorite celebrity what he } \\
\text { say about product }\end{array}$ & & & & & & \\
\hline CRF2 & $\begin{array}{l}\text { I am attracted to products endorsed by } \\
\text { celebrities. }\end{array}$ & & & & & & \\
\hline CRF3 & $\begin{array}{l}\text { Celebrity endorsers' image and value } \\
\text { increase their endorsed products' image } \\
\text { and value. }\end{array}$ & & & & & & \\
\hline CRF4 & $\begin{array}{l}\text { Celebrity endorsements increase my } \\
\text { acceptance of their endorsed products. }\end{array}$ & & & & & & \\
\hline & Expertise & \multirow[t]{5}{*}{0.18} & \multirow[t]{5}{*}{0.000} & \multirow{5}{*}{$\begin{array}{l}.756 \\
.771 \\
.776 \\
.795\end{array}$} & \multirow[t]{5}{*}{68.29} & \multirow{5}{*}{$\begin{array}{l}.859 \\
.802 \\
.820 \\
.823\end{array}$} & \multirow[t]{5}{*}{.896} \\
\hline EXF1 & $\begin{array}{l}\text { Expertise of celebrity regarding the } \\
\text { endorsed product increases my } \\
\text { motivation towards product. }\end{array}$ & & & & & & \\
\hline EXF2 & $\begin{array}{l}\text { If Celebrity endorsers are skilled and } \\
\text { qualified, they can change my opinion } \\
\text { about the product. }\end{array}$ & & & & & & \\
\hline EXF3 & $\begin{array}{l}\text { If celebrity endorsers are experienced } \\
\text { and knowledgeable, they can trigger my } \\
\text { purchase to their endorsed products. }\end{array}$ & & & & & & \\
\hline \multirow[t]{2}{*}{ EXF4 } & $\begin{array}{l}\text { Expertise of the celebrity can be an } \\
\text { attribute that can influence my purchase } \\
\text { decision. }\end{array}$ & & & & & & \\
\hline & Attractiveness & \multirow[t]{5}{*}{.279} & \multirow[t]{5}{*}{0.000} & \multirow{5}{*}{$\begin{array}{l}.744 \\
.754 \\
.719 \\
.798\end{array}$} & \multirow[t]{5}{*}{62.56} & \multirow{5}{*}{$\begin{array}{l}.740 \\
.856 \\
.771 \\
.796\end{array}$} & \multirow[t]{5}{*}{.843} \\
\hline ATF1 & $\begin{array}{l}\text { Celebrity endorsements increase the } \\
\text { attractiveness Of their endorsed brands. }\end{array}$ & & & & & & \\
\hline ATF2 & $\begin{array}{l}\text { Attractiveness of endorsing celebrity is } \\
\text { very important to me. }\end{array}$ & & & & & & \\
\hline ATF3 & $\begin{array}{l}\text { Celebrity endorsements increase the } \\
\text { value of their endorsed products. }\end{array}$ & & & & & & \\
\hline \multirow[t]{2}{*}{ ATF4 } & $\begin{array}{l}\text { Brands with celebrity endorsement can } \\
\text { grab my attention. }\end{array}$ & & & & & & \\
\hline & Compatibility & \multirow[t]{3}{*}{.228} & \multirow[t]{3}{*}{0.000} & \multirow{3}{*}{$\begin{array}{l}.767 \\
.818 \\
.772 \\
.820\end{array}$} & \multirow[t]{3}{*}{66.15} & \multirow{3}{*}{$\begin{array}{l}.848 \\
.778 \\
.841 \\
.785\end{array}$} & \multirow[t]{3}{*}{.797} \\
\hline CMF1 & $\begin{array}{l}\text { Compatible with the product, celebrity } \\
\text { endorsers can trigger my belief to their } \\
\text { endorsed products. }\end{array}$ & & & & & & \\
\hline CMF2 & $\begin{array}{l}\text { Compatibility of celebrity endorsers } \\
\text { with product is very important. }\end{array}$ & & & & & & \\
\hline
\end{tabular}




\begin{tabular}{|c|c|c|c|c|c|c|c|}
\hline CMF3 & $\begin{array}{l}\text { Compatibility of the celebrity can be } \\
\text { an attribute that can influence my } \\
\text { purchase decision. }\end{array}$ & & & & & & \\
\hline CMF4 & $\begin{array}{l}\text { Compatibility of celebrity endorsers } \\
\text { attracts me towards the attributes of } \\
\text { the product. }\end{array}$ & & & & & & \\
\hline & Consumer buying Behavior & \multirow[t]{5}{*}{.128} & \multirow[t]{5}{*}{0.000} & \multirow{5}{*}{$\begin{array}{l}.851 \\
.858 \\
.766 \\
.820\end{array}$} & \multirow[t]{5}{*}{72.75} & \multirow{5}{*}{$\begin{array}{l}.842 \\
.827 \\
.901 \\
.840\end{array}$} & \multirow[t]{5}{*}{.829} \\
\hline CBF1 & $\begin{array}{l}\text { Celebrity endorsements can help me } \\
\text { to make the buying decision. }\end{array}$ & & & & & & \\
\hline $\mathrm{CBF} 2$ & $\begin{array}{l}\text { Celebrity endorsements affect my } \\
\text { selection of alternative brands during } \\
\text { evaluation process. }\end{array}$ & & & & & & \\
\hline CBF3 & $\begin{array}{l}\text { I intend to buy the products which } \\
\text { endorsed by celebrities. }\end{array}$ & & & & & & \\
\hline $\mathrm{CBF} 4$ & $\begin{array}{l}\text { Highly attractive celebrity endorsers } \\
\text { can trigger my purchase to their } \\
\text { endorsed products. }\end{array}$ & & & & & & \\
\hline
\end{tabular}

\section{Table 4.4: Occupation of Respondents}

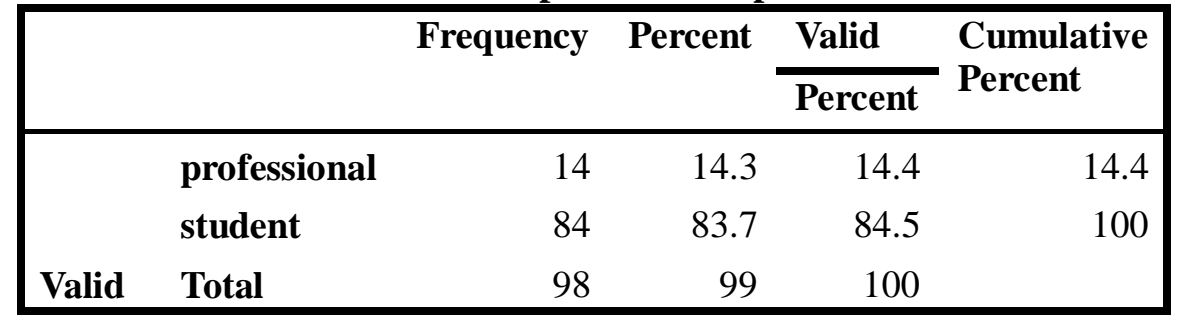

Respondents were requested to mention their occupation while filling the questionnaire. There were total of 98 respondents in which, majority were students i.e. $83.7 \%$ while the rest $14.3 \%$ were professionals.

Table 4.5: Model Summary ${ }^{\mathrm{a}}$

\begin{tabular}{|lllll|}
\hline Model & R & R Square & Adjusted R Square & Std. Error of the Estimate \\
\hline 1 & $.883^{\mathrm{a}}$ & .780 & .770 & .49567 \\
\hline a. Predictors: (Constant), CMF, CRF, EXF, ATF & \\
\hline
\end{tabular}

In the model summary table the value of $\mathrm{R}$ is .883 which tells that independent variable of the Celebrity is $88.3 \%$ correlated with Consumer Buying Behavior. The value of $\mathrm{R}$ square shows that the $78 \%$ variation in dependent variable is explained by the independent variable of the Celebrity, whereas rest of the variation in dependent variable is explained by extraneous variable. Where $\mathrm{R}$ square is adjusted for degree of freedom it reduces to $77 \%$. 
Table 4.6: ANOVA $^{\text {b }}$

\begin{tabular}{|c|c|c|c|c|c|c|}
\hline \multicolumn{2}{|l|}{ Model } & $\begin{array}{l}\text { Sum of } \\
\text { Squares }\end{array}$ & df & $\begin{array}{l}\text { Mean } \\
\text { Square }\end{array}$ & \multirow{2}{*}{$\frac{F}{80.5}$} & \multirow{2}{*}{$\frac{\text { Sig. }}{.000^{\mathrm{a}}}$} \\
\hline 1 & Regression & 79.121 & 4 & 19.78 & & \\
\hline & Residual & 22.357 & 91 & 0.246 & & \\
\hline & Total & 101.479 & 95 & & & \\
\hline \multicolumn{7}{|c|}{ a. Predictors: (Constant), CMF, CRF, EXF, ATF } \\
\hline \multicolumn{7}{|c|}{ b. Dependent Variable: CBF } \\
\hline
\end{tabular}

In the ANOVA table the value F-statistical is 80.510 and $\mathrm{P}$ value of 0.000 shows that the model of study is statistical significant even at $95 \%$.

Table 4.7: Coefficients ${ }^{\mathrm{a}}$

\begin{tabular}{|c|c|c|c|c|c|c|}
\hline \multirow{2}{*}{\multicolumn{2}{|c|}{ Model }} & \multicolumn{2}{|c|}{$\begin{array}{l}\text { Unstandardized } \\
\text { Coefficients }\end{array}$} & \multirow{2}{*}{$\begin{array}{l}\begin{array}{l}\text { Standardized } \\
\text { Coefficients }\end{array} \\
\text { Beta }\end{array}$} & \multirow[b]{2}{*}{$\mathrm{t}$} & \multirow[b]{2}{*}{ Sig. } \\
\hline & & B & $\begin{array}{l}\text { Std. } \\
\text { Error }\end{array}$ & & & \\
\hline 1 & (Constant) & -0.54 & 0.231 & & -2.33 & 0.022 \\
\hline & CRF & 0.394 & 0.076 & 0.376 & 5.19 & 0.000 \\
\hline & EXF & 0.158 & 0.094 & 0.134 & 1.67 & 0.098 \\
\hline & ATF & 0.049 & 0.106 & 0.042 & 0.46 & 0.644 \\
\hline & $\mathrm{CMF}$ & 0.505 & 0.107 & 0.436 & 4.73 & 0.000 \\
\hline
\end{tabular}

a. Dependent Variable: $\mathrm{CBF}$

The regression model, intercept term shows that value of the dependent variable (Consumer Buying Behavior), if the independent variables are credibility, expertise, attractiveness and compatibility. While credibility and compatibility are significant at significant values are 0.000 of both at $95 \%$ confidence interval. Consumer Buying Behavior value would be .459 when the independent variable Credibility of Celebrity equals to zero. $\mathrm{P}$ value of the intercept term is 0.000 which shows that this estimate is statistically significant even at $99 \%$. As per the result of the study, 1 unit increase in the Credibility of Celebrity factor leads to increase of .394 in dependent variable i.e. Consumer Buying Behavior. 1 unit increase in the expertise of Celebrity factor leads to increase of .158 in dependent variable i.e. Consumer Buying Behavior. 1 unit increase in the Attractiveness of Celebrity factor leads to increase of .049 in dependent variable i.e. Consumer Buying Behavior. 1 unit increase in the Compatibility of Celebrity factor leads to increase of .505 in dependent variable i.e. Consumer Buying Behavior. The Expertise and attractiveness are insignificant at significant value of .098 and .644. According to the above finding the $\mathrm{H} 1$ and $\mathrm{H} 4$ are accepted while $\mathrm{H} 2$ and $\mathrm{H} 3$ are rejected. 
Table 4.8: Model Summary ${ }^{\mathrm{a}}$

\begin{tabular}{|l|l|l|l|l|}
\hline Model & R & R Square & Adjusted R Square & Std. Error of the Estimate \\
\hline 1 & $.873^{\mathrm{a}}$ & .762 & .759 & .50593 \\
\hline
\end{tabular}

In the model summary table the value of $\mathrm{R}$ is .873 which tells that independent variable Celebrity endorsement is $87.3 \%$ correlated with Consumer Buying Behavior. The value of $\mathrm{R}$ square shows that the $76.2 \%$ variation in dependent variable is explained by the independent variable of the Celebrity endorsement, whereas rest of the variation in dependent variable is explained by extraneous variable. Where $\mathrm{R}$ square is adjusted for degree of freedom it reduces to $75.9 \%$.

Table 4.9: ANOVA $^{\mathrm{b}}$

\begin{tabular}{|llccccc|}
\hline Model & & Sum of Squares & df & Mean Square & F & Sig. \\
\hline 1 & Regression & 78.543 & 1 & 78.543 & 306.851 & $.000^{\text {a }}$ \\
& Residual & 24.573 & 96 & .256 & & \\
$\quad$ Total & 103.115 & 97 & & & \\
a. Predictors: (Constant), CEF & & & & \\
b. Dependent Variable: CBF & & & & \\
\hline
\end{tabular}

In the ANOVA table the value F-statistical is 306.851 and $\mathrm{P}$ value of 0.000 shows that the model of study is statistical significant even at $95 \%$.

Table 4.10: Coefficients ${ }^{\mathrm{a}}$

\begin{tabular}{|c|c|c|c|c|c|}
\hline \multirow[t]{2}{*}{ Model } & \multicolumn{2}{|c|}{$\begin{array}{l}\text { Unstandardized } \\
\text { Coefficients }\end{array}$} & \multirow{2}{*}{$\begin{array}{l}\text { Standardized } \\
\text { Coefficients } \\
\text { Beta }\end{array}$} & \multirow[b]{2}{*}{$\mathrm{t}$} & \multirow[b]{2}{*}{ Sig. } \\
\hline & $\mathrm{B}$ & $\begin{array}{l}\text { Std. } \\
\text { Error }\end{array}$ & & & \\
\hline $1 \quad$ (Constant) & -0.624 & 0.233 & & & 0.009 \\
\hline CEF & 1.121 & 0.064 & 0.873 & 17.5 & 0.000 \\
\hline
\end{tabular}

a. Dependent Variable: $\mathrm{CBF}$

The regression model, intercept term shows that value of the dependent variable (Consumer Buying Behavior), if the independent variables are celebrity endorsement. Celebrity endorsement is significant at significant values are 0.000 of $95 \%$ confidence interval. Whereas t-statistic is 17.517.As per the result of the study, 1 unit increase in the Celebrity endorsement leads to increase of 1.121 in dependent variable i.e. Consumer Buying Behavior. According to the above findings $\mathrm{H} 5$ is accepted. 
Table 4.11: Correlation Analysis

\begin{tabular}{|l|rrrrrr|}
\hline & CRF & EXF & ATF & CMF & CBF & CEF \\
\hline CRF & 1 & & & & & \\
EXF & 0.613 & 1 & & & & \\
ATF & 0.71 & 0.723 & 1 & & & \\
CMF & 0.674 & 0.766 & 0.794 & 1 & & \\
CBF & 0.781 & 0.728 & 0.752 & 0.826 & 1 & \\
CEF & 0.854 & 0.871 & 0.909 & 0.91 & 0.873 & 1 \\
\hline
\end{tabular}

The correlation table shows the association between variables. Credibility is $61.3 \%$ associated with expertise. Credibility is $71 \%$ associated with attractiveness. Credibility is $67.4 \%$ associated with compatibility. Credibility is 78.1 associated with consumer buying behavior. While credibility is $85.4 \%$ associated with celebrity endorsement. Expertise is $72.3 \%$ associated with attractiveness. Expertise is $76.6 \%$ associated with compatibility. Expertise is $72.8 \%$ associated with consumer buying behavior. Expertise is $87.1 \%$ associated with celebrity endorsement. Attractiveness is $79.4 \%$ associated with compatibility. Attractiveness is $75.2 \%$ associated with consumer buying behavior. Attractiveness is $90.9 \%$ associated with celebrity endorsement. Compatibility is $82.6 \%$ associated with consumer buying behavior. Compatibility is $91 \%$ associated with celebrity endorsement. And consumer buying behavior is $87.3 \%$ associated with celebrity endorsement.

\subsection{Conclusion and Recommendation}

The purpose of study was to find out the influence of celebrity endorsement on the consumer buying behavior by developing testable hypothesis and empirical testing. For analyzing the data descriptive statistics and regression analysis were performed. After conducting the research we came across the conclusion that the selection of celebrity endorsers with the right attributes is crucial to the success of celebrity endorsement. It is because celebrity endorsements can help to create and reinforce the value and image of the products. Thus the markets must carefully evaluate the celebrities and make sure the image which perceived by the target customers are positive. The company must have thorough consideration and sufficient research before the endorsement takes place. They must understand the preference and purchase behavior of their target customers. So that the marketers can react to customer and market changes rapidly. In summary, celebrity endorsement is an effective promotion tool. The companies must select the right celebrity endorsers in order to grab the attentions and arouse the interest of the target customers.

\subsection{Limitations and Future Research}

In this research, there are some limitations. Firstly, the target respondents of the research should be from males and females from different age groups, however due to the time constraints and the snow balling effects, most of the respondents are students. Secondly, the sample of the present research is not derived from probability sampling and therefore the data obtained should be treated with caution. Moreover, the sample population s is relatively small to be a formal marketing research. Future studies could analyze or can work on finding other traits of the celebrity endorsers such as 
trustworthiness, celebrity-consumer matchup etc. that can influence consumer buying behavior.

\section{References}

Atkin, C., \& Block, M. (1983). Effectiveness of Celebrity Endorsers. Journal of advertising research, 57-61.

Belch, G., \& Belch, M. (2001). Advertising and Promotion: An integrated Marketing Communications Perspective (5th ed.). Boston: Irwin/MaGraw- Hill.

Debevec, K., \& Kernan, J. B. (1984). More Evidence On The Effects Of A Presenter's Attractiveness Some Cognitive, Affective, And Behavioral Consequences. Advances in Consumer Research, 11, 127-132.

Endorgan, B. (1999). Celebrity Endorsement: A literature review. Journal of marketing management, 15, 291-314.

Evans, R. B. (1998). Production and Creativity in Advertising. London: Pitman Publishing.

Friedman , H., \& Friedman, L. (1979). Endorser effectiveness by product type. Journal of Advertising Research, 19(5), 67-71.

Hovland, C., Janis, I. L., \& Kelley, H. H. (1953). Communication and Persuasion: Yale University Press.

Kaikati, J. (1987). Celebrity advertising: a review and synthesis. International Journal of Advertising, 6, 93-105.

Kanungo, R., \& Pang, S. (1973). Effects of human models on perceived product quality. Journal of Applied Psychology, 57, 172-178.

Katyal, S. (2007). Retrieved from www.chillibreeze.com/articles/

McCracken, G. (1989). Cultural foundation of the endorsement process (Vol. 16).

McCracken, G. (1989). Who is the celebrity Endorser? Cultural Foundations of the Endorsement Processll. Journal of consumer research, 16, 310-321.

Rossiter, J.R. \& Percy, L. (1987). Advertising and Promotion Management London. McGraw-Hill, Inc.

Spielman, H. (1981). The celebrity sell: making it work. Marketing times, 28, 13-14.

Sternthal, B., Dholakia, R., \& Leavitt, C. (1978). The Persuasive Effect of Source Credibility: Tests of Cognitive Response. Journal of Consumer Research, 4(4), 252-260.

Tellis, G. (1998). Persuasion Using Endorsers. Advertising and sales promotion strategy.

Till, B. D., \& Busler, M. (1998). Matching Products with Endorser: Attractiveness versus Expertise. Journal of Consumer Marketing, 15(6), 576-586. 